\title{
BK virus infection, replication, and diseases in pediatric kidney transplantation
}

\author{
Philip D. Acott • Hans H. Hirsch
}

Received: 28 November 2006 / Revised: 17 January 2007 / Accepted: 1 February 2007 / Published online: 22 March 2007

(C) IPNA 2007

\begin{abstract}
Polyomavirus-associated nephropathy is diagnosed in $2-8 \%$ of pediatric renal transplants and often precedes renal allograft dysfunction. Without intervention, however, significant graft dysfunction is observed in more than $50 \%$ of cases, although progressive early graft loss is reported in only three of $32(9 \%)$ of cases. No specific treatment is available, but early decrease in immunosuppression is followed by declining human polyomavirus type 1 (BK virus) replication and improved outcome. The data suggest differences between pediatric and adult kidney transplantation. Possibly, pediatric patients might be able to mount a more vigorous BK virus-specific immune response than adult patients under similar modulation of immunosuppression. Also the role of cidofovir and leflunomide is still unresolved in pediatric patients. Larger prospective trials are needed to better define the impact of BK virus
\end{abstract}

P. D. Acott

Departments of Pediatrics and Pharmacology,

Dalhousie University,

Halifax, Nova Scotia, Canada

P. D. Acott

Division of Pediatric Nephrology, IWK Health Center,

5850 University Avenue,

Halifax, Nova Scotia, Canada

H. H. Hirsch $(\bowtie)$

Transplantation Virology, Medical Microbiology,

University of Basel,

Petersplatz 10,

4003 Basel, Switzerland

e-mail: hans.hirsch@unibas.ch

\section{H. H. Hirsch}

Infectious Diseases and Hospital Epidemiology,

University Hospital Basel,

Basel, Switzerland immunity for replication and disease as well as the role of reducing immunosuppression with or without cidofovir or leflunomide in pediatric transplant patients.

Keywords Polyoma $\cdot$ BK virus · Children .

Kidney transplantation · Immunosuppression

$\begin{array}{ll}\text { Abbreviations } \\ \text { AZA } & \text { azathioprine } \\ \text { BKV } & \text { BK virus } \\ \text { CAN } & \text { chronic allograft nephropathy } \\ \text { CMV } & \text { cytomegalovirus } \\ \text { Creat } & \text { creatinine ( } \mu \text { M/liter) } \\ \text { CyA } & \text { cyclosporine A } \\ \text { DD } & \text { deceased donor } \\ \text { ELISA } & \text { enzyme-linked immunosorbent assay } \\ \text { EM } & \text { electron microscopy } \\ \text { HIA } & \text { hemagglutination inhibition assay } \\ \text { IF } & \text { indirect immunofluorescence } \\ \text { MMF } & \text { mycophenolate mofetil } \\ \text { LRD } & \text { living related donor } \\ \text { PCR } & \text { polymerase chain reaction } \\ \text { PVAN } & \text { polyomavirus-associated nephropathy } \\ \text { PRED } & \text { prednisone } \\ \text { RED } & \text { restriction enzyme digestion } \\ \text { SV40 } & \text { simian virus } 40 \\ \text { SRL } & \text { sirolimus } \\ \text { TAC } & \text { tacrolimus }\end{array}$

\section{Introduction}

Kidney transplantation is the treatment of choice for children with end-stage renal disease, showing improving 
organ and patient survival over the past decade [1]. Part of this success is based on falling rates of acute allograft rejection, albeit at the expense of a rising number of infectious complications posttransplant [2]. In this setting, polyomavirus-associated nephropathy (PVAN) has emerged as one of the most formidable challenges [3-5]. PVAN has been initially described in adult patients $[6,7]$, and most data has been obtained from this patient population [8]. In fact, older recipient age of $>50$ years has been identified in some studies as an independent risk factor for PVAN [9]. However, PVAN also occurs in pediatric patients. For the purposes of this review, we will focus on human polyomavirus type 1 [BK virus $(\mathrm{BKV})]$ infection, replication, and disease in pediatric kidney transplant recipients.

\section{BKV in the general population}

Natural transmission of the BKV presumably occurs by respiratory or oral-enteric routes in children at a peak age of $2-5$ years. Although no specific symptoms or signs have been identified, primary BKV replication may not necessarily be asymptomatic but in fact go unnoticed as a "flu-like" disease. Subsequently, BKV establishes nonreplicative, latent infection in renal tubular epithelial cells and uroepithelium [10]. The significance of detecting BKV in placental tissues or in cerebrospinal fluid of children with symptoms or signs of central nervous system disease requires further study [11]. Antibodies to BKV are commonly seen in $60-90 \%$ healthy adults, with most children being BKV seropositive by age 10 years [12, 13]. Differences have been observed between the conventional hemagglutination inhibition assay and the more sensitive enzyme immunoassays (EIA) techniques using BKV virus-like particles.

\section{Pediatric studies postrenal transplantation}

Table 1 details relevant data regarding prevalence of BKV infection, replication, and disease in the pediatric renal transplant population. Alexander et al. [14] screened 52 pediatric renal transplant recipients for polyomavirus replication. BKV was detected in the urine of ten patients $(19 \%)$, in plasma of seven $(13.4 \%)$, and in allograft biopsies as PVAN in four (7.7\%). Evaluation of BKV viruria by electron microscopy (EM) typically requires a viral concentration of $10^{6}-10^{7}$ particles/ml and is therefore not as sensitive as polymerase chain reaction (PCR). This limited sensitivity may account for two cases of BKV viremia without concomitant viruria, or alternatively point to de novo infection in these patients. Ginevri et al. [15] conducted a prospective analysis of 100 pediatric renal transplant patents, with detectable BKV antibody in $70 \%$ at time of transplantation. By nested PCR assays, they found BKV viruria in $26 \%$, BKV viremia in $5 \%$ of cases, three of whom progressed to BKV nephropathy during follow-up. In this study, mycophenolate mofetil (MMF) at baseline

Table 1 Pediatric studies evaluating recipient human polyomavirus type 1 (BKV) antibody status, viruria, viremia, and/or nephropathy

\begin{tabular}{|c|c|c|c|c|c|c|c|c|c|}
\hline Authors & $\begin{array}{l}\text { Study } \\
\text { methodology }\end{array}$ & $\begin{array}{l}\text { Pt. } \\
\text { number }\end{array}$ & $\begin{array}{l}\text { Antibody } \\
\text { detectable }\end{array}$ & $\begin{array}{l}\text { Method } \\
\text { (cutoff titre) }\end{array}$ & $\begin{array}{l}\text { Viruria } \\
(\mathrm{BKV})\end{array}$ & Method & $\begin{array}{l}\text { Viremia } \\
(\mathrm{BKV})\end{array}$ & Method & $\begin{array}{l}\text { PVAN } \\
\text { (BKV) }\end{array}$ \\
\hline $\begin{array}{l}\text { Alexander } \\
\text { et al. [14] }\end{array}$ & Retrospective KT & 52 & N/A & & $19 \%$ & $\mathrm{EM} *$ & $13 \%$ & PCR + RED & $7.7 \%$ \\
\hline $\begin{array}{l}\text { Ginevri } \\
\text { et al. [15] }\end{array}$ & Retrospective KT & 100 & $70 \%$ & $\begin{array}{l}\text { HIA } \\
\quad(\operatorname{pos} \geq 1: 40)\end{array}$ & $26 \%$ & Nested PCR & $5 \%$ & Nested PCR & $3 \%$ \\
\hline $\begin{array}{l}\text { Haysom } \\
\text { et al. [16] }\end{array}$ & $\begin{array}{l}\text { Prospective KT } \\
\text { case control } \\
\text { (age matched 1:1) }\end{array}$ & 18 & $\begin{array}{l}56 \% \\
(39 \%)\end{array}$ & $\begin{array}{l}\text { IF IgG } \\
\quad(\operatorname{pos} \geq 1: 10)\end{array}$ & $\begin{array}{l}33 \% \\
(39 \%)\end{array}$ & $\begin{array}{l}\text { PCR }+ \\
\text { hybridization }\end{array}$ & $6 \%(0 \%)$ & $\begin{array}{l}\text { PCR }+ \\
\text { hybridization }\end{array}$ & $0 \%$ \\
\hline $\begin{array}{l}\text { Herman } \\
\text { et al. [17] }\end{array}$ & Prospective & 46 & N/A & & 20 & $\begin{array}{l}\text { Quantitative } \\
\text { PCR }\end{array}$ & $11 \%$ & $\begin{array}{l}\text { Quantitative } \\
\text { PCR }\end{array}$ & $4.3 \%$ \\
\hline $\begin{array}{l}\text { Hymes } \\
\text { et al. [36] }\end{array}$ & Prospective & 122 & N/A & & N/A & & $16 \%$ & $\begin{array}{l}\text { Quantitative } \\
\text { PCR }\end{array}$ & $6.6 \%$ \\
\hline $\begin{array}{l}\text { Muller } \\
\text { et al. [37] }\end{array}$ & $\begin{array}{l}\text { Cross-sectional KT, } \\
\text { controls }(\mathrm{KD}, \mathrm{n}=35) \\
(\mathrm{KDI}, \mathrm{n}=7)\end{array}$ & 38 & N/A & & $\begin{array}{l}18 \% \\
(\mathrm{KD} 0 \%) \\
(\mathrm{KDI} 0 \%)\end{array}$ & $\begin{array}{l}\text { Nested PCR } \\
+ \text { RED }\end{array}$ & $\begin{array}{c}5 \%(\text { KD } 0 \%) \\
(\text { KDI } 14 \%)\end{array}$ & Nested PCR & $3 \%$ \\
\hline $\begin{array}{l}\text { Smith } \\
\text { et al. [26] }\end{array}$ & $\begin{array}{l}\text { Retrospective, } \\
\text { histology workup } \\
\text { for PVAN }\end{array}$ & 192 & $\begin{array}{l}\text { N/A (subgroup } \\
\text { of PVAN) }\end{array}$ & $\begin{array}{l}\text { BKV VLP } \\
(17 \%)\end{array}$ & N/A & $\begin{array}{l}\text { Quantitative } \\
\text { PCR }(100 \%)\end{array}$ & N/A & $\begin{array}{l}\text { Quantitative } \\
\text { PCR }(100 \%)\end{array}$ & $3.5 \%$ \\
\hline
\end{tabular}

$P V A N$ polyomavirus-associated nephropathy, $N / A$ not available, $E M$ electron microscopy, $P C R$ polymerase chain reaction, $R E D$ restriction enzyme digestion, $K T$ kidney transplantation, $H I A$ hemagglutination inhibition assay, $I F$ indirect immunofluorescence (cell culture conditions not indicated), KD kidney disease, KDI kidney disease treated with immunosuppression, VLP virus-like particles, Pt patient, * requires $>10^{6}$ particles per $\mathrm{ml}$ and does not distinguish between BKV and JC virus 
was associated with BKV nephropathy, whereas calcineurin inhibitor choice [tacrolimus vs. cyclosporin A (CyA)] and basiliximab induction were not associated with viruria, viremia, or nephropathy [15]. The role of immunosuppression for BKV replication was also demonstrated in a prospective case-control study of 18 Australian pediatric renal transplants with a seropositivity of $56 \%$ for BKV $\operatorname{IgG}$, of whom $33 \%$ developed viruria as measured by PCR compared with no viruria in the age matched controls that had 39\% seropositivity [16]. Herman et al. [17] found similar prevalence rates for BKV viruria $(20 \%)$, BKV viremia (11\%), and PVAN (4.3\%) in 46 patients followed prospectively. Of note, all of these children received antibody induction therapy in contrast to only $18 \%$ and $22 \%$ of patients studied by Ginevri et al. [15] and Haysom et al. [16], respectively (Table 2). Although more specific studies are needed, the data suggests that induction therapy does not influence prevalence of BKV replication and disease in the pediatric renal transplant population similar to reports in adult kidney transplantation [18], but differences between depleting and nondepleting antibodies and the small sample sizes in these studies should be acknowledged. The role of different calcineurin inhibitors cannot be answered conclusively, as no randomized controlled trials were performed. As can be gathered from Table 2, all combinations can be found among the cases of PVAN in children.

Table 3 summarizes 32 cases of PVAN in pediatrics and the outcomes obtained in individuals younger than 20 years of age. The time point of first diagnosis of PVAN varies considerably from 1 to 48 months after transplant. It is noted that only three allografts $(13 \%)$ were lost in this series, with the majority stabilizing with a reduction of immunosuppressive treatment. There was no uniform strategy for how to reduce immunosuppression as to drug switching, single drug reduction, and reduction of all immunosuppressants. As a common scheme, however, a $30 \%$ reduction in calcineurin-inhibitor dosing, a $50 \%$ reduction in antiproliferative drug dosing, and tapering of steroids to $<10 \mathrm{mg}$ has been common practice. Cidofovir was used in $16 / 32$ patients (Table 3 ) and was associated with a favorable outcome in 13 cases $(81 \%)$, which was not significantly different from that observed in patients treated solely with reduced immunosuppression of $11 / 15(73 \%)$. The role of leflunomide cannot be evaluated from a single case with subsequent graft loss. The mechanism of action of leflunomide and cidofovir is under investigation (for review, see $[19,20])$.

Data from PVAN cases in adults suggest that steroids may be a risk factor for BKV replication and disease, but the role of reducing steroids as part of reducing immunosuppression is not clear. It is important to note that in most patients, BKV viremia will only start to decline for $>1 \log$ after 4-8 weeks. Breakthrough rejection was seen, and often, intense treatment of rejection preceded the recognition of PVAN, as has been reported in some adult studies $[6,18,21]$.

Interstitial infiltrates at the time of diagnosis or following the reduction of immunosuppression in cases with PVAN are difficult to distinguish from acute rejection episodes. BKV-specific immune reconstitution has been associated with declining plasma BKV loads in the peripheral blood [22], which may follow the homing of BKV-specific lymphocytes to the sites of replication in the renal allograft. Considerable controversies exist over the role of adjunct diagnostic markers and the risk/benefit of short courses of steroids [8, 23]. Recent studies applying expression profiling [24] and urine proteomics [25] suggest new diagnostic tools, which are, however, faced with considerable data scatter, and will have to stand the test of prospective studies and the challenge of clinical practice.

Up to now, the data is not sufficient to determine whether or not primary BKV replication in seronegative kidney transplant recipients had a worse outcome compared with seropositive patients with secondary BKV replication. It can be speculated that patients with no or little BKVspecific memory compartment may need more time to mount sufficient control to terminate BKV replication. Only

Table 2 Patient-specific data for pediatric studies evaluating recipient human polyomavirus type 1 (BKV) antibody status, viruria, viremia, and/or nephropathy

\begin{tabular}{|c|c|c|c|c|c|c|c|c|}
\hline Authors & $\begin{array}{l}\text { Induction therapy } \\
\% \text { antilymphocyte } / \% \text { basiliximab }\end{array}$ & PRED (\%) & СyA (\%) & TAC $(\%)$ & RAPA (\%) & MMF (\%) & AZA (\%) & $\begin{array}{l}\mathrm{DD} / \mathrm{LRD} \\
(\%) /(\%)\end{array}$ \\
\hline Alexander et al. [14] & N/A & 100 & 11 & 87 & 16 & 65 & 15 & N/A \\
\hline Ginevri et al. [15] & $0 / 18$ & 100 & 79 & 21 & 0 & 22 & N/A & $95 / 5$ \\
\hline Haysom et al. [16] & $0 / 22$ & 100 & 61 & 39 & 0 & 56 & N/A & $83 / 17$ \\
\hline Herman et al. [17] & 100 (either) & 100 & 54 & 41 & N/A & 28 & 63 & $78 / 22$ \\
\hline Hymes et al. [36] & $0 / 100$ & 100 & 12.5 & 87.5 & 50 & 50 & 12.5 & N/A \\
\hline Muller et al. [37] & $8 / 0$ & 100 & 61 & 39 & 0 & 71 & 0 & $61 / 39$ \\
\hline
\end{tabular}

PRED prednisone, $C y A$ cyclosporine, $T A C$ tacrolimus, $R A P A$ rapamycin, $M M F$ mycophenolate mofetil, $A Z A$ azathioprine, $D D$ deceased donor, $L R D$ living related donor, $N / A$ not available 


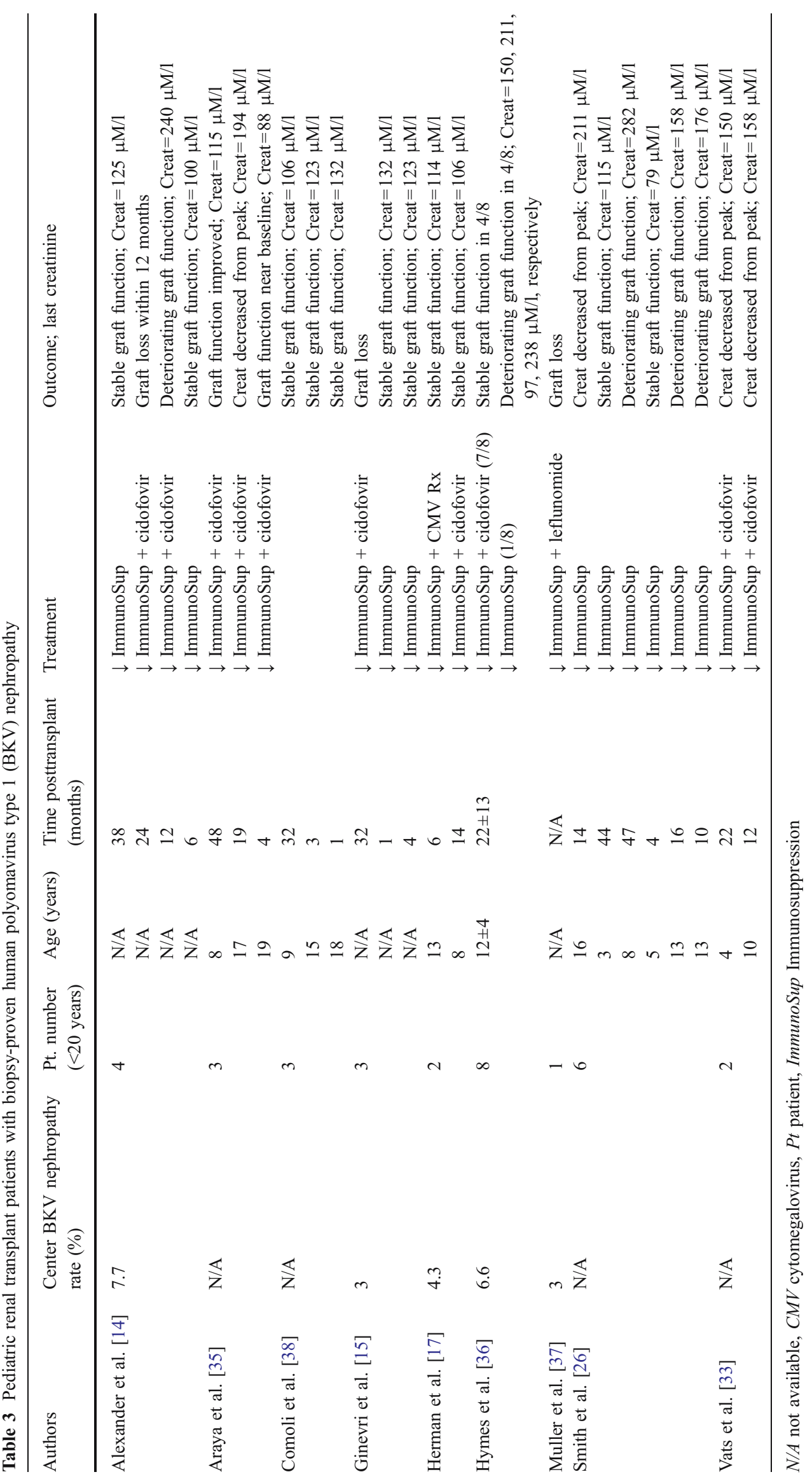


three children were identified as 5 years of age or younger. A retrospective study of 173 pediatric renal transplant patients had similar results, with six patients $(3.5 \%)$ having PVAN a median of 15 months posttransplantation with functioning grafts during follow-up of a median of 28 months [26]. This study noted in the patients with PVAN that all had viruria (median $=6.1$ million copies $/ \mathrm{ml}$ ), all had viremia (median $=21,000$ copies $/ \mathrm{ml}$ ), and recipient seronegative status for BKV using the sensitive BKV viruslike particle enzyme-linked immunosorbent assay (ELISA) was a risk factor for developing PVAN [26].

$\mathrm{BKV}$ load in urine and blood has been found to be a helpful marker in identifying pediatric kidney transplant patients at risk of PVAN. Also, the course of plasma BKV loads has been used as a surrogate marker of allograft involvement, according to the results in adult patients [18, $27,28]$. At this point, however, no comparable pediatric data are available indicating that a plasma BKV load threshold of $>10,000$ copies $/ \mathrm{ml}$ for $>3$ weeks is associated with a $93 \%$ sensitivity and specificity of histologically defined, e.g., definitive, PVAN. Even in adult patients, there are only few prospective studies addressing this issue. In a prospective study from the University of Maryland Transplant Center in Baltimore, MD, USA. Hirsch together with Drachenberg and Ramos reported a cut-off of 10,000 copies/ml was associated with a sensitivity of $68 \%$ and a specificity of $95 \%$ [29]. The lower sensitivity might be explained by a false negative biopsy result that, in retrospective studies, has been estimated to range from $10 \%$ to $30 \%$ [30] and might be higher in the prospective setting. Similar data for urine viral loads are lacking, and, despite the long-known relationship of urine viral loads being approximately 1,000-fold higher than plasma viral loads [31], no significant viruria threshold has been established. Thus, viruria currently serves as a very sensitive marker to exclude BKV replication but in the positive cases should be confirmed by viremia and eventually biopsy (Fig. 1).

\section{Oncogenic potential}

The transforming potential of $\mathrm{BKV}$ infection has been noted early both in nonnatural experimental hosts and in in vitro tissue culture models. In these models BKV late gene expression/host cell lysis does not occur and the early gene mediated subversion of protooncogene and tumor-suppressor gene functions, particularly by large T-antigen function [4]. BKV-mediated oncogenicity is postulated in a report of a child with an adenocarcinoma of the donor renal allograft pelvis following PVAN virus allograft nephropathy, with regression of secondary tumors and a return to good health after removal of the primary tumor and cessation of immunosuppression [32]. Curiously, one of the pediatric
BKVN patients reported by Vats et al. [33] presented with an echogenic mass that resolved with immunosuppression reduction and treatment with cidofovir. Rubio et al. [34] reported a child with PVAN and Epstein-Barr virus (EBV)related posttransplant lymphoproliferative disease.

\section{Implications for screening programs in pediatrics}

Although PVAN is generally thought to be the result of reactivation of $\mathrm{BKV}$ latent in renal tubules, it may represent a primary infection in younger children. This patient group may respond differently than patients with reactivation of latent virus from the transplanted kidney. Table 4 outlines pediatric patients who may be at higher risk of PVAN. These issues may become key considerations in children when developing a screening program, as both Ginevri et al. [15] and Smith et al. [26] noted recipient seronegativity for BKV antibody was significantly associated with risk of developing PVAN. In these pediatric patients, BKV viruria (six of six evaluated) and BKV viremia (five of five evaluated) preceded PVAN, as reported in adult patients by Hirsch et al. [18]. Alexander et al. [14] described two exceptions of viruria predating viremia, although this group used a less sensitive assessment of BKV viruria (EM for BKV) in comparison with PCR techniques. Herman et al. [17] did find correlation of BKV viremia with $\mathrm{BKV}$ viruria load and noted viruria predated viremia by a few weeks. However, as seropositive recipients may still develop $\mathrm{BKV}$ replication and disease, and more comprehensive data are lacking, it is currently not recommended to universally screen donors and pediatric transplant recipients for $\mathrm{BKV}$ serostatus but for BKV replication.

\section{Summary and clinical relevance}

PVAN affects $2-8 \%$ of pediatric renal transplants and often precedes renal allograft dysfunction. Significant graft dysfunction is observed in more than 50\% of cases, although progressive early graft loss is reported in only three of $32(9 \%)$ of cases. These estimates may reflect a reporting bias and are clearly limited by the lack of larger studies with sufficient follow-up. However, it cannot be excluded that pediatric patients might be able to mount a more vigorous BKV-specific immune response than adult patients under similar modes of immunosuppression. No specific treatment is available, although an improvement is often noted by a judicious decrease in immunosuppression. Dosing strategies to improve the efficacy and minimize the toxicity of cidofovir are emerging, as discussed by Araya et al. [35]. Clearly, randomized controlled trials are needed to prove any benefit of cidofovir in addition to reduced immunosuppression. 
Fig. 1 Screening and treating human polyomavirus type 1 (BKV) replication and disease in kidney transplant

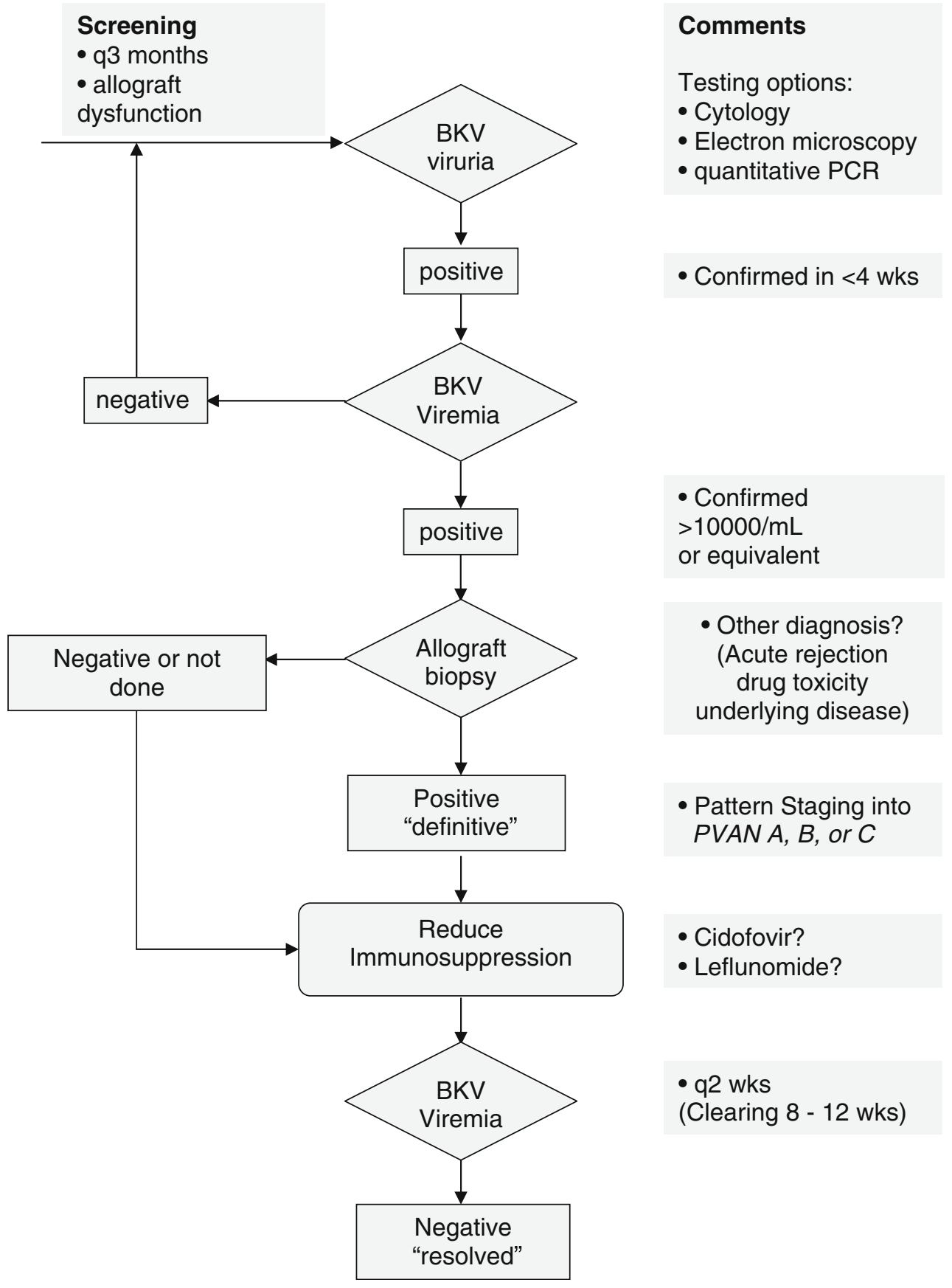

Table 4 Pediatric renal transplant risk factors for polyomavirus-associated nephropathy (PVAN)

Positive BKV viruria $\quad$ BKV antibody mismatch $\quad$ Recipient BKV antibody-negative status

Decoy cells $\quad \mathrm{D}+/ \mathrm{R}-$

$\mathrm{R}-$ and $<5$ years of age

Reduced BKV-specific cellular immunity

Lack of BKV-specific interferon- $\gamma$-secreting lymphocytes in peripheral blood mononuclear cells

Electron microscopy

Quantitative PCR

$B K V$ human polyomavirus type $1, P C R$ polymerase chain reaction, $D+$ donor seropositive, $R$ - recipient seronegative 
Understanding the role of $\mathrm{BKV}$ in transmission, target organ, risk factors, time frame of reactivation, and treatment options will be essential to improving transplant results in terms of patient morbidity, mortality, and graft survival. Understanding the contributions of viral infection and immune regulation in the pediatric renal transplant population would allow development of successful long-term strategies to minimize immunosuppressant drugs, viral injury, and rejection risk to pediatric patients with BKV infection. Until then, screening pediatric transplant patients for $\mathrm{BKV}$ replication by quantitative assays at least 3 monthly for the first 2 years and every time a biopsy is taken for cause or for surveillance will help to improve diagnosis and provide rationales for optimizing immunosuppressive treatment (Fig. 1).

\section{References}

1. Tejani A, Ho PL, Emmett L, Stablein DM (2002) Reduction in acute rejections decreases chronic rejection graft failure in children: A report of the North American Pediatric Renal Transplant Cooperative Study (NAPRTCS). Am J Transplant 2:142-147

2. Dharnidharka VR, Stablein DM, Harmon WE (2004) Posttransplant infections now exceed acute rejection as cause for hospitalization: A report of the NAPRTCS. Am J Transplant 4:384-389

3. Acott PD (2006) Polyoma virus in pediatric renal transplantation. Pediatr Transplant 10:856-860

4. Hirsch HH (2005) BK virus: Opportunity makes a pathogen. Clin Infect Dis 41:354-360

5. Randhawa P, Brennan DC (2006) BK virus infection in transplant recipients: An overview and update. Am J Transplant 6:2000 2005

6. Binet I, Nickeleit V, Hirsch HH, Prince O, Dalquen P, Gudat F, Mihatsch MJ, Thiel G (1999) Polyomavirus disease under new immunosuppressive drugs: A cause of renal graft dysfunction and graft loss. Transplantation 67:918-922

7. Randhawa PS, Finkelstein S, Scantlebury V, Shapiro R, Vivas C, Jordan M, Picken MM, Demetris AJ (1999) Human polyoma virus-associated interstitial nephritis in the allograft kidney. Transplantation 67:103-109

8. Hirsch HH, Brennan DC, Drachenberg CB, Ginevri F, Gordon J, Limaye AP, Mihatsch MJ, Nickeleit V, Ramos E, Randhawa P, Shapiro R, Steiger J, Suthanthiran M, Trofe J (2005) Polyomavirus-associated nephropathy in renal transplantation: Interdisciplinary analyses and recommendations. Transplantation 79:12771286

9. Ramos E, Drachenberg CB, Papadimitriou JC, Hamze O, Fink JC, Klassen DK, Drachenberg RC, Wiland A, Wali R, Cangro CB, Schweitzer E, Bartlett ST, Weir MR (2002) Clinical course of polyoma virus nephropathy in 67 renal transplant patients. J Am Soc Nephrol 13:2145-2151

10. Heritage J, Chesters PM, McCance DJ (1981) The persistence of papovavirus BK DNA sequences in normal human renal tissue. $\mathrm{J}$ Med Virol 8:143-150

11. Behzad-Behbahani A, Klapper PE, Vallely PJ, Cleator GM, Bonington A (2003) BKV-DNA and JCV-DNA in csf of patients with suspected meningitis or encephalitis. Infection 31:374-378
12. Knowles WA, Pipkin P, Andrews N, Vyse A, Minor P, Brown DW, Miller E (2003) Population-based study of antibody to the human polyomaviruses BKV and JCV and the simian polyomavirus sv40. J Med Virol 71:115-123

13. Shah KV, Ozer HL, Pond HS, Palma LD, Murphy GP (1971) Sv40 neutralizing antibodies in sera of us residents without history of polio immunization. Nature 231:448-449

14. Alexander RT, Langlois V, Tellier R, Robinson L, Hebert D (2006) The prevalence of BK viremia and urinary viral shedding in a pediatric renal transplant population: A single-center retrospective analysis. Pediatr Transplant 10:586-592

15. Ginevri F, De Santis R, Comoli P, Pastorino N, Rossi C, Botti G, Fontana I, Nocera A, Cardillo M, Ciardi MR, Locatelli F, Maccario R, Perfumo F, Azzi A (2003) Polyomavirus BK infection in pediatric kidney-allograft recipients: A single-center analysis of incidence, risk factors, and novel therapeutic approaches. Transplantation 75:1266-1270

16. Haysom L, Rosenberg AR, Kainer G, Waliuzzaman ZM, Roberts J, Rawlinson WD, Mackie FE (2004) BK viral infection in an Australian pediatric renal transplant population. Pediatr Transplant $8: 480-484$

17. Herman J, Van Ranst M, Snoeck R, Beuselinck K, Lerut E, Van Damme-Lombaerts R (2004) Polyomavirus infection in pediatric renal transplant recipients: Evaluation using a quantitative realtime pcr technique. Pediatr Transplant 8:485-492

18. Hirsch HH, Knowles W, Dickenmann M, Passweg J, Klimkait T, Mihatsch MJ, Steiger J (2002) Prospective study of polyomavirus type BK replication and nephropathy in renal-transplant recipients. N Engl J Med 347:488-496

19. Josephson MA, Williams JW, Chandraker A, Randhawa PS (2006) Polyomavirus-associated nephropathy: Update on antiviral strategies. Transpl Infect Dis 8:95-101

20. Rinaldo $\mathrm{CH}$, Hirsch HH (2007) Antivirals for the treatment of polyomavirus BK replication. Expert Rev Anti Infect Ther 5:105-115

21. Awadalla Y, Randhawa P, Ruppert K, Zeevi A, Duquesnoy RJ (2004) Hla mismatching increases the risk of BK virus nephropathy in renal transplant recipients. Am J Transplant 4:1691-1696

22. Binggeli S, Egli A, Dickenmann M, Binet I, Steiger J, Hirsch HH (2006) BKV replication and cellular immune responses in renal transplant recipients. Am J Transplant 6:2218-2219

23. Celik B, Shapiro R, Vats A, Randhawa PS (2003) Polyomavirus allograft nephropathy: Sequential assessment of histologic viral load, tubulitis, and graft function following changes in immunosuppression. Am J Transplant 3:1378-1382

24. Mannon RB, Hoffmann SC, Kampen RL, Cheng OC, Kleiner DE, Ryschkewitsch C, Curfman B, Major E, Hale DA, Kirk AD (2005) Molecular evaluation of BK polyomavirus nephropathy. Am J Transplant 5:2883-2893

25. Jahnukainen T, Malehorn D, Sun M, Lyons-Weiler J, Bigbee W, Gupta G, Shapiro R, Randhawa PS, Pelikan R, Hauskrecht M, Vats A (2006) Proteomic analysis of urine in kidney transplant patients with BK virus nephropathy. J Am Soc Nephrol 17:32483256

26. Smith JM, McDonald RA, Finn LS, Healey PJ, Davis CL, Limaye AP (2004) Polyomavirus nephropathy in pediatric kidney transplant recipients. Am J Transplant 4:2109-2117

27. Funk GA, Steiger J, Hirsch HH (2006) Rapid dynamics of polyomavirus type BK in renal transplant recipients. J Infect Dis 193:80-87

28. Vats A (2004) BK virus-associated transplant nephropathy: Need for increased awareness in children. Pediatr Transplant 8:421-425

29. Hirsch HH, Drachenberg C, Ramos J, Papadimitriu, Munivenkatappa R, Nogueira J, Mendley S, Wali R (2006) BK viremia level strongly correlates with the extent/pattern of viral nephropathy (bkpvn) implications for a diagnostic cut-off value. Am J Transplant 6 (S2):460 (abstract 1168) 
30. Drachenberg CB, Papadimitriou JC, Hirsch HH, Wali R, Crowder C, Nogueira J, Cangro CB, Mendley S, Mian A, Ramos E (2004) Histological patterns of polyomavirus nephropathy: Correlation with graft outcome and viral load. Am J Transplant 4:2082-2092

31. Hirsch HH (2002) Polyomavirus BK nephropathy: A (re-) emerging complication in renal transplantation. Am J Transplant 2:25-30

32. Kausman JY, Somers GR, Francis DM, Jones CL (2004) Association of renal adenocarcinoma and BK virus nephropathy post transplantation. Pediatr Nephrol 19:459-462

33. Vats A, Shapiro R, Singh Randhawa P, Scantlebury V, Tuzuner A, Saxena M, Moritz ML, Beattie TJ, Gonwa T, Green MD, Ellis D (2003) Quantitative viral load monitoring and cidofovir therapy for the management of BK virus-associated nephropathy in children and adults. Transplantation 75:105-112

34. Rubio L, Vera-Sempere FJ, Moreno-Baylach MJ, Garcia A, Zamora I, Simon J (2005) LT, VP1 and TCR-BKV sequence analysis in a patient with post-transplant BKV nephropathy associated with EBV-related ptld. Pediatr Nephrol 20:1506-1509

35. Araya CE, Lew JF, Fennell RS, 3rd, Neiberger RE, Dharnidharka VR (2006) Intermediate-dose cidofovir without probenecid in the treatment of BK virus allograft nephropathy. Pediatr Transplant $10: 32-37$

36. Hymes LC, Warshaw BL (2006) Polyomavirus (BK) in pediatric renal transplants: Evaluation of viremic patients with and without BK associated nephritis. Pediatr Transplant 10:920-922

37. Muller A, Beck B, Theilemann K, Stapenhorst L, Licht C, Michalk D, Franzen C, Hoppe B (2005) Detection of polyomavirus $\mathrm{BK}$ and $\mathrm{JC}$ in children with kidney diseases and renal transplant recipients. Pediatr Infect Dis J 24:778-781

38. Comoli P, Azzi A, Maccario R, Basso S, Botti G, Basile G, Fontana I, Labirio M, Cometa A, Poli F, Perfumo F, Locatelli F, Ginevri F (2004) Polyomavirus BK-specific immunity after kidney transplantation. Transplantation 78:1229-1232 